\title{
Perlindungan Hukum Terhadap Tenaga Kerja Asing Berdasarkan Asas Kepastian dan Keadilan
}

\author{
Moch Thariq Shadiqin \\ Fakultas Hukum, Universitas Diponegoro \\ mochthariqshadiqin@students.undip.ac.id
}

\begin{abstract}
The use of foreign workers in Indonesia is increasingly in demand by companies. The Ministry of Manpower of the Republic of Indonesia (Kemnaker) noted that throughout 2016 there were 74,183 TKA in Indonesia). The Foreign Workers are to meet the needs, skilled and professional workforce in specific fields that cannot yet be filled by workers, Indonesia and to encourage the transfer of knowledge and technology. With the normative juridical case approach method, this study conducted to analyze how legal certainty and justice related to regulation. The 1945 Constitution of the Republic of Indonesia states that every citizen has the right to work and a decent life. Consequently, citizens have the right to receive compensation and fair treatment in employment relations and the state has the constitutional responsibility to guarantee the fulfilment of the right to work (TKI) and Foreign Workers (TKA) to create legal certainty and legal protection between them.
\end{abstract}

Keywords : Legal Protection, Foreign workers, Principle of Certainty and Justice.

\begin{abstract}
Abstrak
Penggunaan tenaga kerja asing di Indonesia semakin banyak diminati oleh perusahaan. Kementerian Ketenagakerjaan Republik Indonesia (Kemnaker) mencatat bahwa sepanjang tahun 2016 terdapat 74.183 TKA di Indonesia. Tenaga Kerja Asing tersebut adalah untuk memenuhi kebutuhan, tenaga kerja yang terampil dan professional di bidang tertentu yang belum dapat diisi oleh tenaga kerja, Indonesia serta mendorong alih ilmu dan teknologi. Dengan metode pendekatan kasus yang bersifat yuridis normative, penelitian ini dilakukan untuk menganalisis tentang bagaimana kepastian dan keadilan hukum terkait regulasi. Undang-Undang Dasar Negara Republik Indonesia Tahun 1945 menyebutkan bahwa setiap warga negara berhak atas pekerjaan dan hidup yang layak. Konsekuensinya, warga negara berhak untuk mendapat imbalan dan perlakuan yang adil dalam hubungan kerja dan negara memiliki tanggung jawab konstitusional untuk menjamin terpenuhinya keseimbangan hak atas pekerjaan Tenaga Kerja (TKI) dan Tenaga Kerja Asing (TKA) guna tercipta perlindungan kepastian dan keadilan hukum di antara keduanya.
\end{abstract}

Kata Kunci : Perlindungan Hukum, Tenaga Kerja Asing, Asas Kepastian dan Keadilan.

\section{A. Pendahuluan}

1. Latar Belakang

Dewasa ini penggunaan tenaga kerja asing di Indonesia semakin banyak diminati oleh perusahaan. Dilansir dari money.kompas.com, Kementerian 
Ketenagakerjaan Republik Indonesia (Kemnaker) mencatat bahwa sepanjang tahun 2016 terdapat 74.183 TKA di Indonesia. Tujuan penggunaan Tenaga Kerja Asing tersebut adalah untuk memenuhi kebutuhan tenaga kerja yang terampil dan professional di bidang tertentu yang belum dapat diisi oleh tenaga kerja Indonesia serta mempercepat alih ilmu dan teknologi. Dimana TKA asal China menjadi yang terbesar, yakni sebanyak 21.271 TKA diikuti oleh Jepang sebanyak 12.490 TKA dan Republik Korea sebanyak 8.424 TKA, dam 5.059 tenaga kerja asing asal India. ${ }^{1}$ Keberadaan TKA di pasar kerja Indonesia telah menjadi fenomena yang lumrah mengingat kebutuhan tenaga kerja yang cukup tinggi dan faktor globalisasi.

Faktor globalisasi secara tidak langsung telah memaksa dan mendorong terjadinya pergerakan tenaga kerja antar negara satu dengan yang lainnya. Tenaga Kerja Asing tidak dapat dihindari penggunaannya, dalam era globalisasi yang terjadi di Indonesia ini. Sejatinya penggunaan Tenaga Kerja Asing di Indonesia adalah mereka yang dibutuhkan dalam 2 (dua) hal yakni mereka (Tenaga Kerja Asing) yang membawa modal (sebagai investor) dan/ atau membawa skill dalam hal transfer of knowledge atau transfer of know how ${ }^{2}$ Selain karena kedua hal tersebut maka pada hakekatnya tidak diperkenankan dan harus mengutamakan penggunaan tenaga kerja dari Indonesia (Tenaga Kerja Indonesia). ${ }^{3}$

Dengan semakin banyaknya tenaga kerja asing di Indonesia maka aspek yang paling penting untuk diperhatikan adalah perlindungan hukum terhadap tenaga kerja. Perlindungan hukum terhadap tenaga kerja merupakan pemenuhan hak dasar yang melekat dan dilindungi di dalam konstitusi yakni sebagaimana diatur dalam Pasal 27 ayat (2) UUDNRI Tahun 1945 yang menyatakan “Tiap-tiap warga negara berhak atas pekerjaan dan penghidupan yang layak bagi kemanusiaan". Disebutkan bahwa tiap warga negara artinya hal tersebut tak terkecuali bagi warga negara Indonesia maupun warga negara asing haruslah memiliki kepastian hukum di dalamnya yang memberikan rasa keadilan.

\footnotetext{
${ }^{1}$ https://money.kompas.com/read/2017/07/17/171733726/jumlah-tenaga-kerja-asing-dari-china-di-indonesiatertinggi-sejak, diakses pada tanggal 20/09/2019, puku 17.25

${ }^{2}$ C. Sumarprihatiningrum, Penggunaan Tenaga Kerja Asing di Indonesia, Jakarta: HIPSMI, 2006, hal. 56

${ }^{3}$ Ibid, hal. 57
} 
Perlindungan hukum terhadap tenaga kerja asing sendiri terdapat dalam Peraturan Presiden Nomor 20 Tahun 2018, Undang-Undang Nomor 13 Tahun 2003 tentang Ketenagakerjaan, Keputusan Menteri Tenaga Kerja dan Transmigrasi Nomor 40 Tahun 2012 tentang Jabatan-Jabatan tertentu yang dilarang diduduki tenaga kerja asing, Peraturan Menteri Ketenagakerjaan Nomor 10 Tahun 2018 tentang Tata Cara Penggunaan Tenaga Kerja Asing, Peraturan Menteri Hukum dan Hak Asasi Manusia Nomor 16 Tahun 2018 tentang Tata Cara Pemberian Visa dan Izin Tinggal Bagi Tenaga Kerja Asing.

Secara yuridis dalam hukum ketenagakerjaan kedudukan pengusaha dan pekerja adalah sama dan sederajat. Namun, secara sosiologis pada suatu kondisi tertentu kedudukan antara pekerja atau bisa dikatakan juga sebagai buruh dengan pengusaha tidak sama dan seimbang. Karena seringkali pekerja/buruh berada pada posisi yang lemah. ${ }^{4}$ Maka dari itu di dalam dunia ketenagakerjaan pekerja/buruh adalah kaum yang harus diberikan perlindungan terhadap hakhaknya. Hak-hak pekerja yang diatur Undang-Undang Nomor 13 Tahun 2003 tentang Ketenagakerjaan terdapat pada Pasal 77 hingga Pasal 101 adalah meliputi hak-hak normatif buruh/pekerja.

Maka, perlindungan terhadap terhadap tenaga kerja asing dirasa sangat perlu dikarenakan untuk mencegah pelanggaran oleh pengusaha maupun pemberi kerja. Selain hal tersebut dengan adanya tenaga kerja asing Indonesia diuntungkan karena dapat memberikan keuntungan bagi tenaga kerja Indonesia dalam hal bertukar pengetahuan hal ini sejalan dengan ketentuan Pasal 45 ayat (1) UU Nomor 13 Tahun 2003. Dalam hal perlindungan hukum tenaga kerja asing perlu diberikan perlindungan hukum yang sama dalam memperoleh perlakuan yang sama agar tercapainya keadilan di negara Indonesia serta memastikan bahwa Indonesia merupakan negara yang welcome terhadap persaingan dunia dan aman bagi tenaga kerja asing.

Berdasakan uraian di atas penulis tertarik untuk mengangkat judul "Perlindungan Hukum Tenaga Kerja Asing Berdasarkan Asas Kepastian dan Keadilan".

\footnotetext{
${ }^{4}$ Fenny Natalia Khoe, Hak Pekerja Yang Sudah Bekerja Namun Belum Menandatangani Perjanjian Kerja Atas Upah Ditinjau Berdasarkan Undang-Undang Nomor 13 tahun 2003 tentang Ketenagakerjaan (Jurnal Ilmiah Mahasiswa Universitas Surabaya Volume 2 Nomor 1, 2013), halaman 3
} 


\section{Kerangka Teori}

a. Tenaga Kerja Asing

Definisi tenaga kerja sendiri adalah Tenaga Kerja adalah setiap orang yang mampu melakukan pekerjaan guna menghasilkan barang dan atau jasa baik untuk memenuhi kebutuhan sendiri maupun untuk kebutuhan masyarakat. ${ }^{5}$ Sedang tenaga kerja asing menurut Undang- Undang Nomor 13 Tahun 2003 tentang Ketenagakerjaan, Tenaga Kerja Asing adalah warga negara asing pemegang visa dengan maksud bekerja di wilayah Indonesia. ${ }^{6}$

b. Asas Keadilan

Asas hukum merupakan sebuah aturan dasar atau merupakan prinsip hukum yang masih bersifat abstrak. Maka dapat dikatakan bahwa asas di dalam hukum merupakan dasar yang melatarbelakangi suatu peraturan yang bersifat konkrit dan bagaimana hukum itu dapat dilaksanakan. Peraturan perundang-undangan tidak boleh bertentangan dengan asas hukum.

Demikian pula dengan implementasi atau pelaksanaan hukum dalam kehidupan sehari-hari serta segala putusan hakim pun harus senantiasa mengacu pada asas dalam hukum tidak boleh bertentangan dengannya. Asas hukum merupakan pikiran dasar yang umum dan bersifat abstrak serta bukan merupakan hukum yang konkrit. Namun asas hukum terdapat dalam setiap sistem hukum dan menjelma dalam setiap hukum positif sehingga dapat ditemukan dengan menelusuri sifat-sifat umum dalam peraturan hukum. ${ }^{7}$

Pengertian asas menurut pendapat Sudikno Mertokusumo bahwa asas hukum bukan merupakan hukum konkrit, melainkan merupakan pikiran dasar yang umum dan abstrak, atau merupakan latar belakang peraturan konkrit yang terdapat dalam dan di belakang setiap sistem hukum yang terjelma dalam Peraturan Perundang-Undangan dan putusan hakim yang

\footnotetext{
${ }^{5}$ Muhammad Azhar, Buku Ajar Hukum Ketenagakerjaan, Semarang, 2015, hlm. 8

${ }^{6}$ Undang -Undang Nomor 13 Tahun 2003 tentang Ketenagakerjaan Pasal 1 angka 13

${ }^{7}$ Dewi Astutty Mochtar,Pengantar Ilmu Hukum, Malang: Bayumedia Publishing, 2012, hlm. 77
} 
merupakan hukum positif dan dapat ditemukan dengan mencari sifat-sifat atau ciri-ciri yang umum dalam peraturan konkrit. ${ }^{8}$

Senada dengan pendapat Gustav Radbruch bahwa ketiga nilai dasar hukum adalah keadilan, kegunaan, dan kepastian hukum. Artinya keadilan menjadi salah satu hal yang dituntut dalam suatu peraturan perundang-undangan. ${ }^{9}$

Asas keadilan memiliki peranan yang penting dalam penerapan perekrutran tenaga kerja asing di Indonesia. Adil tidak harus sama rata, namun sesuai dengan porsinya dalam arti bahwa peraturan mengenai tenaga kerja asing tidak boleh mengesampingkan tenaga kerja lokal dalam arti tenaga kerja Indonesia itu sendiri.

Maka hukum sangat penting dalam mencapai suatu tujuan yang salah satunya adalah keadilan. Menurut Lawrence M. Friedman "hukum itu merupakan gabungan antara komponen struktur, substansi dan kultur"' ${ }^{10}$

c. Perlindungan Hukum

Perlindungan hukum selalu terkait dengan peran dan fungsi hukum sebagai pengatur dan perlindungan terhadap kepentingan masyarakat. Broin Malinowski dalam bukunya "Crime and Costum In Savege", mengatakan bahwa hokum tidak hanya berperan di dalam keadaankeadaan yang penuh kekerasan dan pertentangan, akan tetapi bahwa hukum juga berperan pada aktivitas sehari-hari. ${ }^{11}$

Perlindungan hukum bagi pekerja sangat diperlukan mengingat kedudukan pekerja berada pihak yang lemah. Perlindungan terhadap pekerja dimaksudkan untuk menjadi terpenuhinya hak-hak dasar pekerja dan menjamin kesempatan serta perlakuan tanpa diskriminasi atas dasar apapun untuk mewujudkan kesejahteraan pekerja.

d. Asas Kepastian

Kepastian hukum secara normatif yaitu ketika suatu peraturan yang dibuat dan diundangkan secara pasti karena mengatur secara jelas dan

\footnotetext{
${ }^{8}$ Sudikno Mertokusumo, Mengenal Hukum(Suatu Pengantar), Yogyakarta; Universitas Atmajaya , 2010, hlm. 43

${ }^{9}$ Satjipto Rahardjo, Ilmu Hukum, Semarang : PT. Citra Aditya Bakti, 2014, hlm. 19

${ }^{10}$ Esmi Warassih,Pranata Hukum Sebuah Telaah Sosiologis, Semarang; PT Suryandaru Utama, 2005, hlm. 33

${ }^{11}$ Soeroso,Pengantar Ilmu Hukum, Jakarta; Sinar Grafika 2006, hlm. 16
} 
logis. Jelas dalam artian tidak menimbulkan keragu-raguan (multitafsir) dan logis dalam artian menjadi suatu sistem norma dengan norma lain sehingga tidak menimbulkan benturan atau menimbulkan konflik norma. Konflik norma yang ditimbulkan dari ketidakpastian aturan dapat berbentuk kontestasi norma, reduksi norma, atau distorsi norma. Menurut Sudikno Mertokusumo kepastian hukum adalah jaminan bahwa hukum dijalankan, bahwa yang berhak menurut hukum dapat memperoleh haknya dan bahwa putusan dapat dilaksanakan. Meski kepastian hukum erat kaitannya dengan keadilan, namun hukum tidak identik dengan keadilan. Hukum bersifat umum, mengikat setiap orang, bersifat menyamaratakan, sedangkan keadilan bersifat subjektif, individualistis, dan tidak menyamaratakan. ${ }^{12}$

3. Permasalahan

Untuk memecahkan isu hukum di atas, maka dalam penulisan ini diperinci secara mendalam ke dalam dua sub rumusan masalah meliputi :

a. Bagaimana kepastian hukum terhadap penerimaan Tenaga Kerja Asing di Indonesia berdasarkan UU Nomor 13 Tahun 2003 tentang Ketenagakerjaan?

b. Apakah perlindungan hukum terhadap tenaga kerja asing telah memenuhi asas keadilan ?

\section{Metode Penelitian}

Tipe penelitian dalam penyusunan jurnal ini menggunakan penelitian doktrinal research, didasarkan pada metode penelitian yuridis normatif, yaitu pendekatan secara teoritis melalui studi kepustakaan dengan berpijak pada peraturan perundang-undangan yang ada yaitu Undang-Undang Nomor 13 Tahun 2003 tentang Ketenagakerjaan terutama yang mengatur tentang perlindungan terhadap tenaga kerja asing atas keadilan serta peraturan perundang-undangan lainnya yang mengatur tentang tenaga kerja asing, teori-teori atau pendapat ahli hukum yang berkaitan dengan materi penulisan yang akan dibahas. Sedangkan, tipe penelitian secara normatif maksudnya adalah untuk menguraikan norma-norma dalam pasal-pasal yang ada.

\section{B. Pembahasan}

${ }^{12}$ Sudikno Mertokusumo, 2008, Mengenal Hukum Suatu Pengantar. Yogyakarta: Liberty, hlm. 13 
1. Kepastian hukum terhadap penerimaan Tenaga Kerja Asing di Indonesia berdasarkan UU Nomor 13 Tahun 2003 tentang Ketenagakerjaan.

Salah satu isi di dalam Undang-Undang Nomor 13 Tahun 2003 tentang Ketenagakerjaan (UU Ketenagakerjaan) adalah penggunaan tenaga kerja asing yang tetap, yang sesuai dengan kompetensi yang diperlukan. Ketentuan yang terkait dengan penggunaan tenaga kerja asing tertuang dalam Bab VIII mulai dari pasal 42 hingga pasal 49. Ketentuan tersebut menjabarkan untuk memenuhi kebutuhan pasar kerja nasional terutama dalam mengisi kekosongan keahlian dan kompetensi di bidang tertentu yang tidak dapat dilakukan oleh tenaga kerja Indonesia. Sehingga tenaga kerja asing yang dapat dipekerjakan di Indonesia sepanjang dalam hubungan kerja untuk jabatan tertentu dan waktu tertentu saja. Mempekerjakan tenaga kerja asing dapat dilakukan oleh pihak manapun sesuai dengan ketentuan di atas kecuali pemberi kerja orang perseorangan (lihat pasal 42 ayat 2 UU No. 13 Tahun 2003).

Selanjutnya di dalam Pasal 42 ayat (3) dan (4) disebutkan bahwa setiap pemberi kerja yang mempekerjakan tenaga kerja asing wajib memiliki izin tertulis dari menteri atau pejabat yang ditunjuk kecuali terhadap perwakilan negara asing yang mempergunakan tenaga kerja asing sebagai pegawai diplomatic dan konsuler. Lebih lanjut mengenai ketentuan mengenai jabatan tertentu dan waktu tertentu bagi tenaga kerja asing selain dijabarkan dalam Pasal 42 ayat (5) ditetapkan dengan keputusan Menteri, yaitu Keputusan Menteri Nomor : KEP173/MEN/2000 tentang Jangka Waktu Izin Mempekerjakan Tenaga Kerja Warga Negara Asing Pendatang.

Selain harus memiliki izin mempekerjakan tenaga kerja asing, sebelumnya pemberi kerja harus memiliki rencana penggunaan tenaga kerja asing yang disahkan oleh Menteri atau pejabat yang ditunjuk kecuali bagi instansi pemerintah, badan-badan internasional dan perwakilan negara asing. Ketentuan mengenai tata cara pengesahan rencana penggunaan tenaga kerja asing diatur oleh Keputusan Menteri yaitu Kepmenakertrans Nomor: Kep.228/MEN/2003 tentang Rencana Penggunaan Tenaga Kerja Asing (RPTKA). Di dalam RPTKA ini minimal memuat :

a. Alasan penggunaan tenaga kerja asing; 
b. Jabatan dan/atau kedudukan tenaga kerja asing dalam struktur organisasi perusahaan yang bersangkutan;

c. Jangka waktu penggunaan tenaga kerja asing;

d. Penunjukan tenaga kerja warga negara Indonesia sebagai pendamping tenaga kerja asing yang dipekerjakan untuk alih teknologi dan alih keahlian dari tenaga kerja asing.

Terhadap setiap pengajuan atau rencana penggunaan tenaga kerja asing di Indonesia harus dibatasi baik dalam jumlah maupun bidang-bidang yang dapat diduduki oleh tenaga kerja asing.

Terdapat pula jabatan-jabatan yang dilarang yang harus diperhatikan oleh si pemberi kerja sebelum mengajukan penggunaan tenaga kerja asing. Selain harus mentaati ketentuan tentang jabatan, juga harus memperhatikan standar kompetensi yang berlaku. Ketentuan tentang jabatan dan standar kompetensi didelegasikan ke dalam bentuk keputusan menteri. Sayangnya, dalam praktik masih menggunakan aturan yang tidak sesuai dengan UU Ketenagakerjaan baik yang lahir karena pendelegasian maupun karena atribusi.

Kehadiran tenaga kerja asing dikatakan sebagai salah satu pembawa devisa bagai negara. Hal ini terlihat terlihat dari adanya pembayaran kompensasi atas setiap tenaga kerja asing yang dipekerjakannya. Pembebasan pembayaran kompensasi ini diberikan kepada pemberi kerja tenaga kerja asing kecuali instansi pemerintah, perwakilan negara asing, badan-badan internasional, lembaga sosial, lembaga keagamaan, dan jabatan-jabatan tertentu di lembaga pendidikan (vide Pasal 3 Keputusan Menteri Tenaga Kerja dan Transmigrasi Nomor 223 Tahun 2003 tentang Jabatan-jabatan di Lembaga Pendidikan yang Dikecualikan dari Kewajiban Membayar Kompensasi). Besarnya dana kompensasi untuk tenaga kerja Indonesia di luar negeri sebesar US\$ 15, sedangkan kompensasi untuk tenaga kerja asing di Indonesia sebesar US\$100 (PP Nomor 98 Tahun 2000).

Dalam rangka pelaksanaan Transfer of Knowledge (ToK), dari tenaga kerja asing kepada tenaga kerja Indonesia, kepada pemberi kerja diwajibkan untuk mengadakan pendidikan dan pelatihan bagi tenaga kerja pendamping 
(Pasal 49 UU Ketenagakerjaan). Pengaturan tersebut dengan Keputusan Presiden yang sampai saat ini belum ditetapkan.

Meski telah terdapat regulasi yang mengatur demikian. Namun apabila kita cermati lebih dalam UU Ketenagakerjaan tidak mengatur tenaga kerja asing secara terperinci, sehingga sejumlah pengaturan tersebut masih dijabarkan dalam peraturan-peraturan pelaksana fleksibel yang dampaknya mudah dilakukan perubahan aturan-aturan tersebut.

Salah satunya adalah aturan-aturan yang terdapat pada Peraturan Menteri Ketenagakerjaan tahun 2015, pada peraturan ini telah mengalami perubahan sebanyak 2 (dua) kali yaitu Peraturan Menteri Ketenagakerjaan Nomor 16 Tahun 2015 telah diubah oleh Peraturan Menteri Ketenagakerjaan Nomor 35 Tahun 2015. Salah satunya adalah penghapusan kewajiban bagi pemberi kerja untuk menyerap sekurang-kurangnya 10 orang TKI apabila mempekerjakan 1 TKA serta tidak ada lagi ketentuan WNA untuk dapat berbahasa Indonesia. Artinya bahasa Indonesia bukan suatu keharusan. Dengan demikian akan memberikan dampak negatif dan dampak positif seperti banyaknya tenaga kerja asing yang berbondong-bondong ke Indonesia tidak belajar berbahasa Indonesia, tidak terhambatnya masuk modal asing, sedangkan dampak negatifnya adalah menghambat alih teknologi dari tenaga kerja asing kepada TKI pendamping. Persyaratan lain yang banyak dilanggar dalam praktiknya seperti jabatan atau bentuk pekerjaan yang dapat dilakukan oleh tenaga kerja asing. ${ }^{13}$

Selain hal di atas permasalahan hukum juga muncul yakni Bab VI Pasal 42-49 mengenai penggunaan tenaga kerja asing dan diatur lebih lanjut pada Peraturan Menteri Ketenagakerjaan Nomor 35 Tahun 2015 tentang Perubahan Atas Peraturan Menteri Ketenagakerjaan Nomor 16 Tahun 2015 tentang Tata Cara Penggunaan tenaga kerja asing khususnya pada Pasal 36 ayat (1).

\footnotetext{
${ }^{13}$ Risky Vista Puspita Sari, dkk. 2018. Kepastian Hukum Pengaturan Tenaga Kerja Asing di Indonesia. (Jurnal Ilmiah Lentera Universitas Jember Volume 5 Nomor 3, 2018), halaman 376
} 
Namun, pengaturan penggunaan tenaga kerja asing dalam Peraturan Menteri Ketenagakerjaan Nomor 35 Tahun 2015 tentang Tata Cara Penggunaan Tenaga Kerja Asing tidak berkepastian hukum melihat beberapa Pasal yang mengetatkan dan membebaskan penggunaan tenaga kerja asing pada Pasal 3, Pasal 36 ayat (1) dan Pasal 40 ayat (2) Peraturan Menteri Ketenagakerjaan Nomor 16 Tahun 2015 diatur bahwa DKP-TKA yang dibayarkan harus dikonversi ke Rupiah. Permenaker Nomor 35 Tahun 2015 menghapuskan ketentuan ini. Penghapusan ini bertentangan dengan Undang-Undang Nomor 7 Tahun 2011 tentang Mata Uang.

2. Perlindungan hukum terhadap tenaga kerja asing telah memenuhi asas keadilan

Tak hanya kepastian hukum terhadap tenaga kerja asing-pun pemerintah sebenarnya telah menerapkan asas keadilan di dalam UU Ketenagakerjaan. Keadilan bukan berarti harus sama. Namun, keadilan yang dimaksudkan di sini adalah tetap memperhatikan dan mengutamakan tenaga kerja lokal atau tenaga kerja Indonesia. Hal tersebut tercantum UU Nomor 13 Tahun 2003 Tentang Ketenagakerjaan Bab VIII mengenai Penggunaan Tenaga Kerja Asing Pasal 46.

\section{Pasal 46}

(1) Tenaga kerja asing dilarang menduduki jabatan yang mengurusi personalia dan/atau jabatan-jabatan tertentu.

(2) Jabatan-jabatan tertentu sebagaimana dimaksud pada ayat (1) diatur dengan Keputusan Menteri

Terhadap tenaga kerja asing dilarang menduduki jabatan yang mengurusi personalia dan/atau jabatan-jabatan tertentu yang selanjutnya diatur dengan Keputusan Menteri Tenaga Kerja dan Transmigrasi Nomor 223 Tahun 2003 tentang Jabatan-jabatan di Lembaga Pendidikan yang Dikecualikan dari Kewajiban Membayar Kompensasi.

Selain hal di atas mengenai pengaturan jabatan diatur lebih rigid dalam Keputusan Menteri Ketenagakerjaan Nomor 13 Tahun 2015 tentang Jabatan Yang Dapat Diduduki Oleh Tenaga Kerja Asing Pada Kategori Jasa Persewaan, Ketenagakerjaan, Agen Perjalanan dan Penunjang Usaha lainnya, kelompok Jasa Penyeleksian dan Penempatan Tenaga Kerja Dalam Negeri, Nomor 14 Tahun 2015 tentang Jabatan Yang Dapat Diduduki Oleh Tenaga Kerja Asing Kategori Industri Pengolahan, Subgolongan Industri Furnitur, Nomor 15 Tahun 2015 
Administrative Law \& Governance Journal. Volume 2 Issue 3, August 2019| ISSN. 2621 - 2781 Online

tentang Jabatan Yang Dapat Diduduki Oleh Tenaga Kerja Asing Pada Kategori Industri Pengolahan, Subgolongan Industri Alas Kaki, Nomor 16 Tahun 2016 tentang Jabatan Yang Dapat Diduduki Oleh Tenaga Kerja Asing Pada Kategori Penyediaan Akomodasi dan Penyediaan Makan Minum Golongan Pokok Penyediaan Akomodasi dan Penyediaan Makanan dan Minuman, Nomor 17 Tahun 2015 tentang Jabatan Yang Dapat Diduduki Oleh Tenaga Kerja Asing Pada Kategori Industri Pengolahan, Subgolongan Industri Rokok dan Cerutu, Nomor 25 Tahun 2015 tentang Jabatan Yang Dapat Diduduki Oleh Tenaga Kerja Asing Pada Kategori Industri Pengolahan , Sub Golongan Industri Gula, dan yang terakhir Nomor 12 Tahun 2015 tentang Jabatan Yang Dapat Diduduki Oleh Tenaga Kerja Asing Pada Kategori Pertanian, Kehutanan dan Perikanan, Golongan Peternakan.

Sehingga setiap pengajuan atau rencana penggunaan tenaga kerja asing di Indonesia telah dibatasi baik dalam jumlah maupun bidang-bidang yang dapat diduduki oleh tenaga kerja asing. Hal tersebut bertujuan agar kehadiran tenaga kerja asing di Indonesia bukanlah dianggap sebagai ancaman yang cukup serius bagi tenaga kerja Indonesia, justru kehadiran mereka sebagai pemicu bagi tenaga kerja Indonesia untuk lebih professional lagi dan selalu meningkatkan dirinya agar dapat bersaing baik antara sesama tenaga kerja Indonesia maupun dengan tenaga kerja asing. Oleh karenanya UU Ketenagakerjaan membatasi jabatanjabatan yang dapat diduduki oleh tenaga kerja asing.

\section{Simpulan}

Meski telah terdapat regulasi yang mengatur mengenai TKA. Namun, apabila kita cermati lebih dalam UU Ketenagakerjaan tidak mengatur tenaga kerja asing secara terperinci, sehingga sejumlah pengaturan tersebut masih dijabarkan dalam peraturan-peraturan pelaksana yang fleksibel sehingga dampaknya mudah dilakukan perubahan aturan-aturan tersebut.

Perlindungan tenaga kerja asing di Indonesia telah memenuhi asas keadilan hal ini dibuktikan dalam setiap pengajuan/rencana penggunaan tenaga kerja asing di Indonesia telah dibatasi untuk menjamin keadilan bagi TKA maupun TKI baik dalam jumlah maupun bidang-bidang yang dapat diduduki oleh tenaga kerja asing. Hal tersebut bertujuan agar kehadiran tenaga kerja asing di Indonesia tidaklah dianggap 
sebagai ancaman yang cukup serius bagi tenaga kerja Indonesia, justru kehadiran mereka sebagai pemicu bagi tenaga kerja Indonesia untuk lebih professional lagi dan selalu meningkatkan dirinya agar dapat bersaing baik antara sesama tenaga kerja Indonesia maupun dengan tenaga kerja asing. Oleh karenanya UU Ketenagakerjaan membatasi jabatan-jabatan yang dapat diduduki oleh tenaga kerja asing.

\section{Daftar Pustaka}

C. Sumarprihatiningrum, 2006, Penggunaan Tenaga Kerja Asing di Indonesia, Jakarta: HIPSMI.

Esmi Warassih, 2005, Pranata Hukum Sebuah Telaah Sosiologis, Semarang : PT Suryandaru Utama.

https://money.kompas.com/read/2017/07/17/171733726/jum lah-tenaga-kerja-asing-dari-china-di-indonesia-tertinggisejak, diakses pada tanggal 20/09/2019, pukul 17.25.

Keputusan Menteri Ketenagakerjaan Nomor 14 Tahun 2015 tentang Jabatan Yang Dapat Diduduki Oleh Tenaga Kerja Asing Kategori Industri Pengolahan, Subgolongan Industri Furnitur.

Keputusan Menteri Ketenagakerjaan Nomor 15 Tahun 2015 tentang Jabatan Yang Dapat Diduduki Oleh Tenaga Kerja Asing Pada Kategri Industri Pengolahan, Subgolongan Industri Alasa Kaki.

Keputusan Menteri Ketenagakerjaan Nomor 12 Tahun 2015 tentang Jabatan Yang Dapat Diduduki Oleh Tenaga Kerja Asing Pada Kategori Pertanian, Kehutanan dan Perikanan, Golongan Peternakan

Keputusan Menteri Ketenagakerjaan Nomor 13 Tahun 2015 tentang Jabatan Yang Dapat Diduduki Oleh Tenaga Kerja Asing Pada Kategori Jasa Persewaan, Ketenagakerjaan, Agen Perjalanan dan Penunjang Usaha liannya, kelompok Jasa Penyeleksian dan Penempatan Tenaga Kerja Dalam Negeri.

Keputusan Menteri Ketenagakerjaan Nomor 16 Tahun 2016 tentang Jabatan Yang Dapat Diduduki Oleh Tenaga Kerja Asing Pada Kategori Penyediaan Akomodasi dan Penyediaan Makan Minum Golongan Pokok Penyediaan Akomodasi dan Penyediaan Makanan dan Minumam.

Keputusan Menteri Ketenagakerjaan Nomor 17 Tahun 2015 tentang Jabatan Yang Dapat Diduduki Oleh Tenaga Kerja Asing Pada Kategori Industri Pengolahan, Subgolongan Industri Rokok dan Cerutu.

Keputusan Menteri Ketenagakerjaan Nomor 25 Tahun 2015 tentang Jabatan Yang Dapat Diduduki Oleh Tenaga Kerja Asing Pada 
Kategori Industri Pnegolahan, Sub Golongan Industri Gula, dan yang terakhir.

Keputusan Mentri Tenaga Kerja dan Transmigrasi Nomor 40 Tahun 2012 tentang Jabatan-Jabatan tertentu yang dilarang diduduki tenaga kerja asing

Khoe, Fenny Natalia, 2013, Hak Pekerja Yang Sudah Bekerja Namun Belum Menandatangani Perjanjian Kerja Atas Upah Ditinjau Berdasarkan Undang- Undang Nomor 13 tahun 2003 tentang Ketenagakerjaan, Jurnal Ilmiah Mahasiswa Universitas Surabaya Volume 2 Nomor 1.

Mochtar, Dewi Astutty dkk.,2012, Pengantar Ilmu Hukum, Malang : Bayumedia Publishing.

Muhammad Azhar, 2015, Buku Ajar Hukum Ketenagakerjaan, Semarang.

Peraturan Mentri Hukum dan HAM Nomor 16 Tahun 2018 tentang Tata Cara Pemberian Visa dan Izin Tinggal Bagi Tenaga Kerja Asing.

Peraturan Mentri Ketenagakerjaan Nomor 10 Tahun 2018 tentang Tata Cara Penggunaan Tenaga Kerja Asing, Peraturan Mentri Hukum dan Hak Asasi Manusia

Peraturan Presiden Nomor 20 Tahun 2018 tentang Penggunaan Tenaga Kerja Asing

Risky Vista Puspita Sari, dkk, 2018, Kepastian Hukum Pengaturan Tenaga Kerja Asing di Indonesia, (Jurnal Ilmiah Lentera Universitas Jember Volume 5 Nomor 3, 2018), halaman 376

Satjipto Rahardjo, 2014, Ilmu Hukum, Semarang : PT. Citra Aditya Bakti.

Soeroso, 2006, Pengantar Ilmu Hukum, Jakarta : Sinar Grafika.

Sudikno Mertokusumo, 2008, Mengenal Hukum(Suatu Pengantar), Yogyakarta : Liberty.

Sudikno Mertokusumo, 2010, Mengenal Hukum(Suatu Pengantar), Yogyakarta; Universitas Atmajaya .

Undang-Undang Dasar Negara Republik Indonesia Tahun 1945

Undang-Undang Nomor 13 Tahun 2003 tentang Ketenagakerjaan

Undang-Undang Nomor 13 Tahun 2003 tentang Ketenagakerjaan

Undang-Undang Nomor 7 Tahun 2011 tentang Mata Uang 